\title{
University Drop-Outs. A Systemic Play of Subjects, Institutions and Macro Contexts
}

\author{
Miriam Aparicio
}

Main rechearcher CONICET (National Council of Scientific Research).Cuyo National University

miriamapar@yahoo.com; maparici@satlink.com.ar

Doi:10.5901/jesr.2014.v4n2p466

\begin{abstract}
This paper is a part of a wider research program concerning the assessment of quality at University. It was selected by the Department of University Policies (Ministry of Education, Science and Innovation) in an attempt to determine the causes and "reasons" underlying dropping school in our country. The Program includes three sub-projects concerning both academic and socio-professional success, delay and failure (dropping out). Our specific aim here is to determine the psychosocial reasons for failure at University (qualitative aspect). The sample includes University students who quit studies at UNCuyo in a period of nearly 20 years (1987-2004). A quanti-qualitative methodology was applied so as to be able to explain and more fully understand the importance of the causes and the reasons underlying their quitting. 212 indicators were used. Results show different profiles connected with the same variables/psychosocial dimensions ( $n$-ach, expectations, fatalism, self-efficacy, life projects, social representations of the importance of university degrees in relation with insertion in the labor market, etc) underlying drop-outs.
\end{abstract}

Keywords: Evaluation - Quality - University - Drop-out - Psychosocial profiles - Identities

\section{Introduction}

This study is part of a broad research program on university quality evaluation. It was awarded the University Policies Department Price, and it aimed at studying the causes for drop-outs at universities in Argentina. The program includes sub-projects developed along these lines: success (graduates); delay (students protracting their studies over the time fixed by the curriculum); and failure (here, desertion), analyzed at two interacting levels: academic and sociocultural. It was, in fact, assumed that among the determining achievement factors at university and in the work environment within the last decade could be the country structural situation in addition to the degree "devaluation" in the labor market.

This sub-project aims at accounting for the psychosocial "sources" of failure at university, for this is a problem that, despite the great proportions it has reached worldwide, and being of considerable concern in Argentina ${ }^{1}$, has not been sufficiently studied from an integrating systemic approach that could recover the core, structural, sociocultural and institutional factors interacting with the psychosocial one. Starting from these detected gaps, we work following the sui generis systemic method (Cfr. Aparicio, 2005, 2007a; 2007 b) that does not disregard the university, the market or the individual but it considers them within the casual interaction.

Objectives: a) Analyzing the relation between drop-out and core, sociocultural, psychosocial, pedagogical, institutional and structural variables with the view of detecting the principal causes. b) Being aware of the psychosocial aspects most often associated to drop-out in order to recognize the high-risk population and to take the corresponding preventive measures. c) Being aware of the impact of degree devaluation on the work market regarding drop-out.

\section{Brief Theoretical Framework}

\subsection{Explaining Academic Failure}

\subsubsection{Drop-out: Cause or Determining Variables}

There are various causes related to failure, and in addition to this problem there is the unambiguity of the term "failure":

\footnotetext{
${ }^{1}$ The figures for drop-out are really worrying: 60.9\%, considered for all the academic units as a whole. There exist some differences according to faculties, courses of study, cohorts and admission system. 
the definitions refer to different aspects, such as poor performance, course repetition, drop-out, poor education quality, school maladjustment, etc. Failure is also linked to physiological, psychobiological and family background factors; to interaction with teachers: to interrelation of such different factors as intelligence, sex, type of educational institution, the effects that the family sociocultural level has on performance, etc. Others associate it to social origin (hyperculturalisms) or to the influence of other psychological factors (anxiety, immaturity, inhibition, aggressiveness, etc.).

If we narrow the scope of approaches to the university area exclusively, failure is primarily "the drop-out of studies and the repetition of courses" (González Tirados, 1984). It is associated to the excessive length of the studies, overcrowding, poor teacher's commitment, lack of expectations as a consequence of the growing unemployment, working while studying, etc. There are other factors like poor teaching quality, shortage of vocational guidance, large number of students per course, lack of selection within some courses of study, overabundance of theory over practice, little communication between teachers and students in mass-based university systems, etc.

On the other hand, most publications from international organizations make reference to statistic data only (dropout, repetition rates, etc.). Even though the information evidences the seriousness of the matter and its wide spreading, it is not enough to draw conclusions on possible causes. A number of theories, perspectives and models often show fragmentary and/or reductionist aspects of failure (hypersociologisms, hyperculturalisms, among others).

Leaving literature aside and considering only our study, we have noticed the "presence" of the factors already mentioned, which could have an impact on drop-out on students as well as on teachers.

\subsubsection{Achievement Related Approaches}

Studies by Cabrera, Castañeda and Nora (1992), Braxton, Johnson and Shaw-Sullivan (1997), offer five broad categories to classify the approaches related to dropout and retention, considering whether the emphasis assigned to the core explanatory variables falls on personal, family, or institutional factors. We can identify five approaches: psychological, sociological, economic, organizational and interactionist, which are supported by empirical research.

As regards the psychological approach, the pioneers Fishbeim \& Ajzen (1975) put the emphasis on the role of attitudes, beliefs, and behavioral intentions with respect to achievement. Athináis (1986) includes students' selfperception of university life. Later on, Ethington (1990) and Eccles \& Wigfield (2002) add the role of perseverance, previous academic choice and performance as achievement predictive factors, along with self-concept, perception of obstacles during studies, goal relevance, their ambitions and expectations in view of the fulfillment of their objectives. (Lévy-Leboyer, 1971). A Spanish view of the importance of these factors is presented by Huertas et al (1997). This widely developed approach has changed since the 90's, when more integrating perspectives started to become more important.

As regards the sociological approach of academic achievement, the French School has made important contributions since the 70's, especially from cultural reproductivism (Bourdieu \& Passeron, 1970) and hyperculturalisms with their wide range of perspectives (Bernstein, 1965; Aparicio, 2005). In the US, Spady (1970) considers essential for achievement factors that are still applicable in research: inclusion, social affiliation, building of tight family bonds (related to the information of our research from the notion of resilience).

The economicist models put the emphasis on the cost-benefit ratio students observe between their investments on education and what they expect to obtain from it within the labor market (Becker, 1964; Mingat \& Rasera, 1981, LévyGarboua 1976, 1977; Aparicio, 2007 a; 2007 b).

Finally, the organizational approaches emphasize the opportunities provided by the institutions in terms of extracurricular offers, sports, academic support, bibliographical resources, laboratories, internships, tutoring, etc. The interesting thing is, in our opinion, that these are more easily controllable factors in the managing areas (intervention level) (Corman, Barr \& Caputo, 1992).

Along this line, different models show the impulse of adaptation to university life and acceptance of the fashion or "identity" each institution presents; the role of engagement and positive interactions among students and with teachers, as well as the role of perspective, which, as stated by Tinto $(1975,1987,1993)^{2}$, exhibits an individual side and an

2 Tinto's theory on dropout students is probably the most broadly used theoretical framework in relation to continuance at university. Braxton and Hirschy (1999-2004) consider the theory has an "almost paradigmatic dimension": 775 quotes on the sociological and interactive model. It is similar to Astin's I-E-O model $(1985,1991)$, but its bases are on decisions concerning dropping out or continue with studies. The author claims that, when students enter university, they show different personal and family features, different academic training, skills and goals which undergo a change due to interaction within the academic and social systems, assisted by the external environment influence (expectations, family, friends, etc.). Positive and satisfactory interactions with such systems (formal and informal) 
academic one. Nevertheless, although Tinto is one of the principal writers about this subject, the studies performed along his model do not show stable results in terms of the influence and the sense of the factors put forward. Otherwise, the concept of academic and social inclusion has been objected by other researchers as inappropriate from the general point of view (Corman, Barr \& Caputo, 1992), or as applied to specific groups such as racial or ethnic minorities (Biggs, Torres \& Washington, 1998), or applied to adult students (Spanard, 1990). Whereas Tierney (1992) holds that the model has major limitations; various studies carried out with Caucasians and racial minority show that academic and social inclusion works in the same way in order to account for retention (Cabrera y Nora, 1994). This relationship between socioacademic inclusion and retention has been also observed in studies with representative samples at the national level in the US (Astin, 1993; Horn, 1998; Leppel, 2002; Thompson, 1990; Tinto, 1998) and in studies on a single institution (Eaton \& Bean, 1995; Kelly, 1996; Thomas, 2000). There is also some evidence suggesting that the earlier students start, the better their results are (Gerdes \& Mallinckrodt, 1994; Berger \& Milem, 1999).

Bean $(1980,1983,1985)$ adds the persistence factor to Tinto's model, thus, following Price's model (1977) on behavioral intentions within the business labor framework. He states that institutional (external) factors, such as the programs offered by a university or the interrelationship between students and teachers, may have an impact on the student's decision to endeavor to persevere. Satisfaction with the institutional offer could work in like manner. Therefore, we can see that focus is on organizational/institutional, environmental, and non-cognitive personal factors (ambitions, motivations, interests, etc.).

Later, Robbins (2004) emphasizes the influence of the socioeconomic factors. Pascarella (1985a) suggests, in turn, a model that combines institutional and environmental features, distinguishing five groups: 1) personal features (aptitudes, performance, personality, ambitions, and ethnicity); 2) structural and organizational factors (admission systems, selectivity): 3) environment; 4) interactions within university life; and 5) the quality of students' effort. This last variable, effort, is the core of Pace's model (1979a, 1984, 1987, 1992). On the other hand, Cabrera et al (1992) say that continuance at university rests on three mainstays: economic possibilities, perception of benefits, and a suitable academic and social inclusion.

A more recent approach, the psychosocial approach, claims that it is necessary to test the relationship among motivation, social and institutional constructs (Robbins, Lauver, Le, Davis \& Langley, 2004). This implies considering academic goals, institutional performance, social support, tight bonds (one of the most relevant indicators of resilience), decision-making processes, among others.

We observe that the constructs, despite some differences, describe a series of coincidences, experiences and academic and social forces that could influence on the individuals, globally favoring persistence and completion of studies. In the foregoing methods, the general framework comprising the different components lies in academic and social involvement, i.e, as long as the students feel engaged (Astin 1985) or included within the academic and social systems of their respective institutions (Tinto, 1975, 1987, 1993).

Studies carried out in the US also show that the best predictors for graduation are academic training and students motivation (Adelman, 2004; Pascarella \& Terenzini, 2005). Thus, the institutions are inclined to reinforce selectivity and recruit only "the most brilliant students". However, this strategy - besides being questionable for the system - is practicable only for a few institutions. If we intend to expand the access of all society to higher education or to make a better prepared population for the times to come, increasing selectivity does not seem to be the way.

Compared with the foregoing methods, ours integrate a variety of these factors grouped in the last two approaches: psychological and organizational (see especially Aparicio 2005, 2006 a and b; 2008 a and b). Some variables used in the afore mentioned models are incorporated and the impact of these variables on the subjective and objective achievement is analyzed based on quantitative methodologies and predictive models (Aparicio, 2005); on the other hand, in the light of qualitative methodologies, we intend to account for the origin of this problem and the significance of dropout in the students' personal-professional experiences.

In this study, we deal, especially and always from a qualitative point of view, with the psychosocial aspects of the problem (processes leading to dropout), and the institutional aspects, which have been observed in some typical practices identifying each course of study and, in a more global manner, the university. Both aspects are combined based on an integrating perspective without disregarding the educational institution, nor the individuals and their sociocultural background (close and distant), nor the structural present context. However, the latter is part of our analysis

lead students to a better degree of inclusion within these systems and to perseverance in studies and eventual graduation. Inclusion is, within this framework, the degree in which the individuals share the prescriptive attitudes and values of their peers and teachers, and adhere to the formal and informal demands that being part of a community or subgroup requires. When the degree of inclusion increases, commitment to personal achievement and to the institution permitting such achievement strengthens. 
only as a secondary aspect, whether from the viewpoint of degree devaluation in the labor world, or from the discontent students express (i.e., from their opinions as regards these poor institutional practices in relation to the higher demands of the labor market). All this has an impact on the perseverance and success in studies and employability). Individuals, institutions and macro-social contexts interweave in this analysis.

The meso-institutional and micro-personal levels within a structural background of crisis (underemployment, high unemployment rated, even for university graduates, etc.) are self-sustainable in this integrating and holistic perspective (Aparicio 2008, 2009 a and b, 2009 c, 2011, 2012a , 2012 b). Here lies the uniqueness of our quantitative/qualitative sui generis model.

\subsubsection{Failure: Definition and Operationalization}

Going through international works, there appear two definitions of failure: strictly speaking, it indicates a score below the passing mark, and it is most commonly used. A second meaning defines failure as the absence from the university scene by not sitting for exams and, eventually, separation from it. Within the context of this research, a drop-out is the individual who separates from the system by either or both reasons.

\subsection{Hypotheses}

General Hypothesis: within achievement at university level there exist different factors: individual (objective and subjective), pedagogical, institutional and structural (labor market). Their interaction operates selection in higher education.

Specific Psychosocial Hypotheses: a) Psychosocial factors (combine aspects of the individuals and their context) favor academic and/or work failure. b) Ambitions, expectations and y n-Ach (need achievement) have a specific impact on the selection which operates before and during entering university as well as during the course of studies. c) These factors together with others (pessimism of perspectives, dissatisfaction, anomy, millenarianism, etc.) create achievement patterns which are different according to the courses of study, whether favoring achievement or not. d) All this benefits different institutional identities linked to biographical-contextual identities of the individuals.

\section{Empiric-Methodological Decisions}

This study was carried out in two stages: 1980-1987 and 1988 until present. It involved a significant fieldwork: at-home tracking of over 3,000 drop-outs who entered UNCuyo from 1988 on in 18 different courses of study (Aproximately 30\% of them were found in both instances).

\subsection{Sample}

Consisted of 1,905 individuals, according to institutional records, although only 445 were found and surveyed in their houses. It was carried out in all the courses of study of UNCuyo, except Law, Odontology, Bromatology and Arts. Many different professional life profiles were noticed, especially if we consider that, during such period of time, there were changes in the economic situation and the market, which made insertion, continuance and professional promotion more difficult.

The sampling was stratified, random start and systematic. The sampling error was of 4.4 and the confidence interval was of $95.5 \%$. The survey was carried out at-home.

\subsection{Techniques}

A semi-structuralized type of survey was used which involved different kinds of variables, covering a wide range (212 indicators). The quantitative techniques included interview and non-obstructive observation.

\subsection{Variables}

There were grouped according to the components of the model: 1) core, psychosocial and objective determining factors; 2) pedagogical and institutional factors; 3 ) structural factors (work market). Operationalization implied statistic treatment 
(quantitative) and process analysis (qualitative). The psychosocial factors are dealt qualitatively. Some of the core variables are: Ambitions, Engagement, Value of a university degree, Pessimistic perspective, $\mathrm{N}$-ach, Satisfaction/Dissatisfaction (personal or according to the University/Work), Expectations (personal, academic, at work). All of them provide a way to measure the sense of self-fulfillment, fatalism, instability, lack of regulations, etc.

\section{Results}

This study gives rise to a large amount of relationships between variables and qualitative nodes. At this stage, we choose to define the most relevant psychosocial aspects observed in individuals who abandon schooling as well as the influence that the demands from the work market and the answers given to such demands by Universities have on drop-outs.

Given the variety of relationships, we chose to present the results following two very distinct typologies which, although they are just implied in some existing literature, they captivated us and fall into the under the "consumption model" or "investment model".

According to the investment model, traditionally, the most prestigious courses of study - hard sciences or simple Sciences - which offer limited quotas for admission, or are more demanding as regards attendance and/or full time engagement, but which, in the medium or long term, lead to a more favorable position within the labor market, recruit individuals with different basic, cultural and personal features. In fact, the ones who choose those courses are individuals from high social strata, of lower ages in average, and have reached higher levels of success in secondary school; who belong to families with a higher cultural level and a better socioeconomic situation.

However, at the psychosocial level, they are more ambitious people, more secure, with definite and clear personal goals, committed to their career choice, which they have usually chosen according to their vocation. In addition, they are more self-demanding and more demanding to the institution, which, they think, provide inadequate training in researching and latest methodologies, the poor connection between curriculum contents and the demands from the labor market, etc.

Always, in the "investment" model, the recruitment is for more motivated and hardworking individuals. Although they choose longer and more difficult courses of study, they graduate sooner and in a higher proportion.

The opposite occurs with the individuals that choose less prestigious courses of study (connected to the "soft sciences", according to this typology); they often come from less privileged homes, socioculturally speaking, and have poorer competences and fewer skills during previous academic levels. Their psychosocial profile is clearly different from those within the previous typology as regards expectations, n-Ach, life project, adaptation, fatalism, apathy, dissatisfaction.

Some specific considerations: in these courses of study, those who drop out declared they had not really chosen the course they desired; at the moment of choosing, they prioritized economic factors, job possibilities over vocation and personal fulfillment. They also proved to be less ambitious in general, they decided to enter university for it was "the only thing to do" after high school in a country with labor insertion problems. In addition, they had a very strong self-perception about degree devaluation and a negative self-perception as regards the offer of universities. Many had to study and work at the same time, and they evidenced less enthusiasm and perseverance on their studies; they declared they were not willing to make "sacrifices" as a result of the lack of offer - education; they entered university already considering dropping out if they got a job; many start being very uncertain about finishing studying: their personal goals were quite vague.

As regards their work expectations, they were very low: there appeared high levels of fatalism and discouragement. These individuals drop out, although they choose objectively shorter and less expensive studies. Anyway, what is really interesting is that the relationship between the variables was never linear and, ultimately, the factors influencing such success or failure derive from the very human being; psychosocial individuals who make choices and decisions, take responsibilities or not, take commitments, have an identity, with or without ambitions, who believe in personal and social progress, think effort makes everything possible. On the other hand, there are others who think everything is pre-destined and their life is tainted with fatalism, that everything is determined by chance or luck; or those who take full responsibility, or those who hold the structures responsible for their failures, or those who try to overcome the obstacles structures pose. The decisional / psychosocial factors proved to be significant in dropping out, although drop-out is usually attributed to specific economic factors.

Understanding this success-failure phenomenon demands recovering the individual and his/her environment, the micro, contextual- social, and institutional levels, for each course of study offers different profiles in terms of achievement. There exist, in addition, macro-social and institutional identities - carrying different histories - which interact with personal identities. 


\section{References}

Adelman, C. (2004). Principal Indicators of Student Academic Histories in Postsecondary Education, 1972-2000. Washington, DC: U.S. Department of Education, Institute of Education Sciences. http://www.ed.gov/rschstat/research/pubs/prinindicat/index.html

Aparicio, M. (1995). Educación Superior y Empleo. Propuesta de un modelo sistémico. Ph.D. Thesis, Universidad Católica Argentina Santa María de los Buenos Aires, Argentina.

Aparicio, M. (2003a). Calidad y Universidad. Un análisis desde un modelo multidimensional. Mendoza: Zeta.

Aparicio, M. (2005). Les facteurs psychosociaux en relation avec la réussite universitaire et professionnelle. Université Lille 3: ANRT.

Aparicio, M. (2006a). Trayectorias universitarias. Un análisis a la luz de metodologías cuantitativas. Mendoza: ZETA.

Aparicio, M. (2006b). Trayectorias universitarias: Un análisis a la luz de metodologías cualitativas.Mendoza: ZETA.

Aparicio, M. (2007a). Les facteurs psychosociaux à la base de la réussite universitaire et professionnelle : aspects psychologiques et organisationnels. HDR en Psychologie. Lille: Université de Lille3.

Aparicio, M. (2007b). Mobilité et réussite universitaires et professionnelles. Du niveau macro au niveau micro. HDR en Sciences de l'éducation. Paris: Université Paris X, Nanterre.

Aparicio, M. (2008). Causas de la Deserción en Universidades Nacionales. San Juan: Edit. UNSJ.

Aparicio, M. (2009a). La demora en los estudios universitarios. Causas desde una perspectiva cuantitativa. Vol I. Mendoza: EDIUNC.

Aparicio, M. (2009b). La demora en los estudios universitarios. Causas desde una perspectiva cualitativa. Universidad Nacional de Cuyo, Vol. II. Mendoza: EDIUNC.

Aparicio, M. (2009c). Les facteurs psychosociaux et la réussite universitaire et professionnelle. Lille: ANRT.

Aparicio, M. (2010). Retención y logro en la Universidad: competencias sociales y prácticas institucionales como parámetros de su Calidad. Programa Picto, Agencia Nacional de Investigaciones, Argentina.

Aparicio, M. (2011). Les trajectoires des étudiants, un jeu entre les sujets et leurs contextes institutionnels. Acta Europeana Systemica, On Line Journal of The European Union for Systemics (EUS). (2011, December 07th On Line issue). Vol. 1.

Aparicio, M. (2012a). La deserción universitaria y su relación con factores psicosociales. Revista Dialogo, 20, 28-39.

Aparicio, M. (2012b). Trajectoires universitaires/professionnelles et identité. In J. Clénet, Ph. Maubant \& D. Poisson (Eds.). Formations et professionnalisations : à l'épreuve de la complexité. Paris : L'Harmattan, 195-229

Astin, A. (1984). Student Involvement: A Developmental Theory for Higher Education. Journal of College Student Personnel, 25, 297308.

Astin, A. (1985). Achieving Educational Excellence: A Critical Assessment of Priorities and Practices in Higher Education. San Francisco: Jossey-Bass.

Astin, A. (1991). Assessment for Excellence: The Philosophy and Practice of Assessment and Evaluation in Higher Education. New York: Macmillan.

Astin, A. (1993). What matters in college? Four Critical Years Revisited. San Francisco: Jossey-Bass.

Bean, J. (1980). Dropouts and turnover: The Synthesis and Test of a Causal Model of Student Attrition. Research in Higher Education, $12,155-187$.

Bean, J. \& Metzner, B. (1985). A Conceptual Model of Nontraditional UndergraduateSstudent Attrition. Review of Educational Research, 55, 485-540.

Becker, G. (1964). Human Capital. New York: National Bureau of Economic Research.

Beil, C., Reisen, C., Zea, M. \& Caplan, R. (1999). A longitudinal study of the effects of academic and social integration and commitment on retention. NASPA Journal, 37, 376-385.

Berger, J. \& Milem, J. (1999). The Role of Student Involvement and Perceptions of Integration in a Causal Model of Student Persistence. Research in Higher Education, 40, 641-664.

Bernstein, B. (1965). Langages et classes sociales. Codes sociolinguistiques et contrôle social. Paris: Minuit.

Bertaux, D. (1977). Destins personnels et structures de classe. Paris: PUF.

Biggs, S., Torres, S. \& Washington, N. (1998). Minority Student Retention: A Framework for Discussion and Decision Making. Negro Educational Review, 49, 71-82.

Bisseret, N. (1968 a). La naissance et le diplôme. Les processus de sélection aux débuts des études universitaires. R. Française de Sociol., 9 , $n^{\circ}$ spécial, 185-207.

Bisseret, N. (1968 b). La sélection à l'Université: étude des rapports de dominance. R. Française de Sociol., 9, 463-496.

Bourdieu, P. \& Passeron, J.-C. (1970). La reproduction. Paris: Minuit.

Braxton, J. (1999). Theory Elaboration and Research Development: Toward a fuller Understanding of College Student Retention. Journal of College Student Retention, 1, 93-97.

Braxton, J. \& Hirschy, A. (2004). Modifying Tinto's Theory of College Student Departure using Constructs Derived from Inductive Theory Revision. In M. Yorke \& B. Longden (Eds.), Retention and Student Success in Higher Education. Buckingham, UK: Open University Press.

Braxton, J., Sullivan, A. \& Johnson, R. (1997). Appraising Tinto's Theory of College Student Departure. In J. C. Smart (Ed.), Higher Education: Handbook of Theory and Research (Vol. 12, pp. 107-158). New York: Agathon.

Cabrera, A. \& Nora, A. (1994). College Students'Perceptions of Prejudice and Discrimination and their feelings of Alienation: A Construct Validation Approach. Review of Education/Pedagogy/Cultural Studies, 16, 387-409.

Campbell, T. \& Campbell, D. (1997). Faculty-Student Mentor Program: Effects on Academic Performance and Retention. Research in 
Higher Education, 38, 727-742.

Carey, K. (2004). A Matter of Degrees: Improving Graduation Rates in Four-year Colleges and Universities. The Educational Trust. http://www2.edtrust.org/NR/rdonlyres/11B4283F-104E-4511-B0CA-1D3023231157/0/highered.pdf (consul. 15/10/2008).

Chickering, A. W., \& Reisser, L. (1993). Education and Identity. San Francisco: Jossey-Bass.

Corman, J., Barr, L., \& Caputo, T. (1992). Unpacking Attrition: A Change of Emphasis. Canadian Journal of Higher Education, $23,14-27$.

Donoso, S. \& Schiefelbein, E. (2007). Análisis de los modelos explicativos de retención de estudiantes en la universidad: una visión desde la desigualdad social. Estudios Pedagógicos, 13(1), 7-27.

Eaton, S. \& Bean, J. (1995). An Approach/Avoidance Behavioral Model of College Student Retention. Research in Higher Education, 36, 617-645.

Gerdes, H. \& Mallinckrodt, B. (1994). Emotional, Social, and Academic Adjustment of College Students: A Longitudinal Study of Retention. Journal of Counseling and Development, 72, 284-288.

Goodsell, A. M., Maher, M., \& Tinto, V. (Eds.). (1992). Collaborative Learning: A Sourcebook for Higher Education. University Park: National Center on Postsecondary Teaching, Learning, and Assessment, The Pennsylvania State University.

González Tirados, R. (1984). Análisis de las causas del fracaso escolar en la Universidad Politécnica de Madrid. Madrid: C.I.D.E.

Grayson, J. (1998). Racial Origin and Student Retention in a Canadian University. Higher Education, 36, 323-352.

Halpin, R. (1990). An Application of the Tinto Model to the Analysis of Freshman Persistence in a Community College. Community College Review, 17, 22-32.

Horn, L. (1998). Stopouts or Stayouts? Undergraduates who Leave College in their First Year (Statistical Analysis Report N NCES 1999-087). Washington, DC: U.S. Department of Education, Office of Educational Research and Improvement, National Center for Education Statistics.

Huertas, J. A., Montero, I. \& Alonso Tapia, J. (1997). Principios para la intervención en el aula. In J. A. Huertas. Motivación. Querer aprender. Buenos Aires: Aique.

Johnson, G. (1994). Undergraduate Student Attrition: A Comparison of Students who withdraw and Students who Persist. Alberta Journal of Educational Research, 15, 337-353.

Johnson, J. (1997). Commuter college students: What Factors Determine who will Persist and who will Drop Out? College Student Journal, 31, 323-332.

Kelly, L. (1996). Implementing Astin's I-E-O Model in the Study of Student Retention: A Multivariate Time-dependent Approach. Paper presented at the meeting of the Association of Institutional Research, Albuquerque, NM.

Kuh, G. D. \& Hu, S. (2001). The Effects of Student-Faculty Interaction in the 1990s. Review of Higher Education, 24, $309-332$.

Kuh, G. D., Schuh, J. H., Whitt, E. J. \& Associates. (1991). Involving Colleges: Successful Approaches to Fostering Student Learning and Personal Development Outside the Classroom. San Francisco: Jossey-Bass.

Latiesa, M. (1992). La deserción universitaria. Madrid: CIS.

Leppel, K. (2002). Similarities and Differences in the College Persistent of Men and Women. Review of Higher Education, 25, 433-450.

Lévy-Garboua, L. (1976). Les demandes de l'étudiant ou les contradictions de l'université de masse. R. Française de Sociol., 17( 1), 5380.

Lévy-Garboua, L. (1977). Les demandes de l'étudiant ou les contradictions de l'Université de masse : réponse aux commentaires. R. Française de Sociol., 19(1), 147- 156.

Lévy-Leboyer, C. (1971). L’Ambition professionnelle et la mobilité sociale. Paris: PUF.

Mallette, B. \& Cabrera, A. (1991). Determinants of withdrawal Behavior: An Exploratory Study. Research in Higher Education, 32, 179194.

McCormick, A. (1997). Changes in Educational Aspirations after High School: The Role of Postsecondary Attendance and Context. Paper presented at the meeting of the Association for the Study of Higher Education, Albuquerque, NM.

Mingat A. \& Rasera, J. (1981). Enquête longitudinale 3. Après la première année d'études. Réorientation, réussite, scolarité. Dijon, University de Dijon, IREDU.

Pace, C. (1988). Measuring the Quality of College Student Experiences. Los Angeles: University of California, Center for the Study of Evaluation.

Pascarella, E. (2001). Identifying Excellence in Undergraduate Education: Are we even Close? Change, 33(3), $19-23$.

Pascarella, E. \& Terenzini, P. (1991). How College Affects Students: Findings and Insights from Twenty Years of Research. San Francisco: Jossey-Bass.

Pascarella, E. \& Terenzini, P. (2005). How College Affects Students: A Third Decade of Research (Vol. 2). San Francisco: Jossey-Bass.

Sorcinelli, M. D. (1991). Research Findings on the Seven Principles. In Chickering, A. W, \& Gamson, Z. F. (Eds.), Applying the Seven Principles for Good Practice in undergraduate education,13-25. San Francisco: Jossey-Bass.

Spady, W. (1970). Dropouts from Higher Education: AnInterdisciplinary Review and Synthesis. Interchange, 1, 64-85.

Spanard, J. (1990). Beyond intent: Reentering College to Complete the Degree. Review of Educational Research, 60, 309-344.

Stith, P. (1994). Faculty/student Interaction: Impact on Student Retention. Paper presented at the Meeting of the Association for Institutional Research, New Orleans.

Thomas, S. (2000). Ties that Bind: A Social Network Approach to Understanding Student Integration and Persistence. Journal of Higher Education, 71, 591-615.

Thompson, C. (1990). Predicting Involvement and Educational Attainment: A Study of Black Students in Black and White Colleges. Paper presented at the meeting of the American Educational Research Association, Boston. 
Tierney, W. (1992). An Anthropological Analysis of Student Participation in College. Journal of Higher Education, 63, 603-618.

Tinto, V. (1975). Dropout from Higher Education: A Theoretical Synthesis of Recent Research. Review of Educational Research, 45, 89125.

Tinto, V. (1987). Leaving College: Rethinking the Causes and Cures of Student Attrition. Chicago: University of Chicago Press.

Tinto, V. (1993). Leaving College: Rethinking the Causes and Cures of Student Attrition (2a ed.). Chicago: University of Chicago Press.

Tinto, V. (1998). Colleges as Communities: Taking Research on Student Persistent Seriously. Review of Higher Education, 21, 167-177.

Tinto, V. (2002). Promoting Student Retention: Lessons Learned from the United States. Presented at the 11th Annual Conference of the European Access Network, Prato, Italy. June 19, 2002. 